\title{
Pinus nigra subsp. pallasiana ve Pinus sylvestris tohumlarında Diplodia sapinea'nın yoğunluğu
}

\author{
Funda Oskay a,* (D), Adem Karataș ${ }^{\mathrm{b}}$ [ic
}

\begin{abstract}
Özet: Diplodia sapinea, dünya çapında, çam ağaçlarının bilinen en yaygın ve tehlikeli nekrotrofik patojenlerinden biridir. Patojenle bulaşık kozalak, tohum ve fidan gibi bitki materyallerinin taşınması bu hastalığın uzun mesafelerde yayılışında önemli bir role sahiptir. Fungusun sebep olduğu Diplodia sürgün yanıklığı Türkiye'de yaygınlı̆̆ı ve zararı her geçen gün artan bir hastalıktır. Bununla birlikte, bildiğimiz kadarı ile Türkiye'de bu patojenin çam tohumlarındaki varlığının ve tohumlar aracılığı ile fidanlıklara ve orman alanlarına taşınma riskinin ortaya konulmasına yönelik araştırma bulunmamaktadır. Bu çalışma, iptal edilmiş bazı tohum bahçelerinden toplanan karaçam (Pinus nigra subsp. pallasiana) ve sarıçam (Pinus sylvestris) tohumlarında Diplodia sapinea'nın varlığının ve yoğunluğunun ortaya konulması amacı ile 2017-2018 yıllarında yürütülmüştür. Karşılaştırma amacı ile sağlıklı, aktif durumdaki tohum kaynaklarından temin edilen tohumlar da çalışmaya dahil edilmiştir. İptal edilmiş karaçam ve sarıçam tohum bahçelerinden temin edilen tohumların \%70'inin (sırasıyla ortalama \%72 ve \%57) D. sapinea ile bulaşık olduğu tespit edilmiştir. Buna karşı1lı, aktif tohum kaynaklarından sadece sarıçam tohum meşceresinde tek bir tohumdan $(\% 0,50)$ D. sapinea izole edilmiş, aktif karaçam tohum bahçesinden gelen tohumlarda ise patojen tespit edilmemiştir. Buna ek olarak, iptal edilmiş tohum bahçelerinden gelen karaçam ve sarıçam tohumlarının bindane ağırlıkları ve çimlenmeleri aktif tohum kaynaklarından gelen tohumlardan daha düşük bulunmuştur. Tüm bunlar bir arada değerlendirildiğinde, iptal edilen tohum bahçelerinde tohum kalitesinin azalmasında $D$. sapinea'nın önemli bir rol üstlendiği söylenebilir. Daha da önemlisi, sonuçlar $D$. sapinea'nın $P$. nigra ve $P$. sylvestris tohumları aracılığıyla yayılma potansiyelini doğrulamaktadır.

Anahtar kelimeler: Orman ağacı tohumları, Tohum fungusları, Tohum sağlığı, Diplodia sapinea, Sydowia polyspora, Pinus nigra, Pinus sylvestris
\end{abstract}

\section{Incidence of Diplodia sapinea in Pinus nigra subsp.pallasiana and Pinus sylvestris seed}

\begin{abstract}
Diplodia sapinea, the causal agent of Diplodia shoot blight, is one of the most common and dangerous necrotrophic pathogen of pines worldwide. Movement of plant materials such as cones, seeds and seedlings infected with the pathogen plays an important role in the dissemination of the disease over long distances. While the incidence and damage caused by the pathogen is increasing in Turkey, to our knowledge, the presence of the pathogen on pine seeds and the risk of transmission to nurseries and forest areas through seed movement have not been studied before. This study was carried out between 2017 and 2018 in order to investigate the presence and incidence of Diplodia sapinea in Anatolian black pine (Pinus nigra subsp. pallasiana) and Scots pine (Pinus sylvestris) seeds collected from four abandoned seed orchards in Turkey. Seeds obtained from an active P. nigra seed orchard and a $P$. sylvestris seed stand were also included in the study. D. sapinea was detected on both $P$. nigra and $P$. sylvestris seeds collected from the abandoned seed orchards. On average $70 \%$ of the seeds $(72 \%$ and $57 \%$ for $P$. nigra and $P$. sylvestris respectively) were infected with the pathogen. The pathogen was not detected on seeds from the active $P$. nigra seed orchard, yet was detected on $0.50 \%$ of seeds from the $P$. sylvestris seed stand. Thousand-seed-weights as well as germination of seeds from the abandoned seed orchards were lower than those of active seed sources. Taken together, these findings suggest that $D$. sapinea could have an important role in the reduction of seed quality in the abandoned seed orchards. More importantly, results confirm the potential for dissemination of $D$. sapinea on $P$. nigra and $P$. sylvestris seeds.
\end{abstract}

Keywords: Forest tree seeds, Seed fungi, Seed health, Diplodia sapinea, Sydowia polyspora, Pinus nigra, Pinus sylvestris

\section{Giriş}

Diplodia sapinea (Fr.) Fuckel [syn.; Diplodia pinea (Desm.) J. Kickx f., Sphaeropsis sapinea (Fr.) Dyko \& B. Sutton], dünya çapında, çam ağaçlarının bilinen en yaygın ve tehlikeli fungal patojenlerinden biridir. Fungusun sebep olduğu hastalık; Diplodia sürgün ya da uç yanıklığı olarak adlandırılır. Patojen, sürgün yanıklığı başta olmak üzere, tohum çürüklügüü, çökerten, kök boğazı çürüklüğü, gövde ve dal kanseri ve odunda mavi renklenmeye sebep olmaktadır (Capretti vd., 2013). Fungus 50’ye yakın çam türüne ek olarak Pseudotsuga spp., Abies spp., Picea spp., Larix spp., Cedrus spp. gibi iğne yapraklı türlerde de tespit edilmiştir (Oskay vd., 2018a; Zlatković vd., 2017). Avrupa'da 19. yüzyılın başlarında saprobik bir fungus olarak tanımlanan fungusun zararı ve yaygınlığı 1980'li yıllardan bu yana hızla artmaktadır (Adamson vd., 2015; Blumenstein vd., 2020; Brodde vd., 2018; Müller vd., 2019). Dünya çapında $\begin{array}{lll}凶 & \text { a } & \text { Çankırı Karatekin Üniversitesi Orman Fakültesi, 18200, Çankırı, Türkiye } \\ & \text { b } & \text { Orman Genel Müdürlüğü, Kütahya Orman Bölge Müdürlüğü, Kütahya } \\ @ \quad & * & \text { Corresponding author (İletişim yazarı): fundaoskay@karatekin.edu.tr } \\ \checkmark & \text { Received (Geliş tarihi): 28.06.2021, Accepted (Kabul tarihi): 03.09.2021 }\end{array}$
Citation (Atıf): Oskay, F., Karataş, A., 2021. Pinus nigra subsp. pallasiana ve Pinus sylvestris tohumlarında Diplodia sapinea'nın yoğunluğu. Turkish Journal of Forestry, 22(3): 218-228. DOI: $10.18182 /$ tjf.799849 
patojenin giderek artan zararı, duyarlı çam türleri ile yapılan plantasyonların yoğunlaşması ve çevresel değişimlere atfedilirken, hastalık epidemilerinin siklıkla kuraklık, dolu zararı gibi stres faktörleri ile ilişkili olduğu ortaya konulmuştur (Fabre vd., 2011; Stanosz vd., 2001a). Fungusun konukçularında hastalık belirtisi göstermeden latent olarak kalabildiği (Flowers vd., 2001; Stanosz vd., 2001b; Stanosz vd., 1997; Stanosz vd., 2007), bununla birlikte ağaç fizyolojisinde meydana gelen değişimlerin hastalık simptomlarının ortaya çıkışını teşvik ettiği bilinmektedir (Desprez-Loustau vd., 2006). Buna göre bu firsatçı patojen bitkilerin gövde, dal, ibre, çiçek, kozalak ya da tohumlarını enfekte ettikten sonra bu dokular içerisinde uzun yıllar belirti göstermeden bekleyebilmekte ve nihayetinde konukçusunun strese girmesinin ardından belirtileri ortaya çıkmaktadır (Bihon vd., 2011). Patojenle bulaşık ağaçlarda ilk aşamada tepede deformasyonlar oluşmaya başlarken, uzun yıllar süren enfeksiyonlarda ağaçlar zayıf düşmekte ve herhangi bir stres faktörüne maruz kalan bu ağaçlar tek bir vejetasyon döneminde ölebilmektedir (Blumenstein vd., 2020; Capretti vd., 2013).

Patojen, ölü sürgünler, ibreler ve kozalaklar üzerinde gelişen üreme yapılarından salınan sporlar ile kısa mesafelerde yayılır (Capretti vd., 2013). Bununla birlikte, kozalak, tohum ve fidan gibi bitki materyalleri fungusun uzun mesafelere yayılışında önemlidir (Burgess ve Wingfield, 2002; Stanosz vd., 2007). Belirti göstermeyen bitkilerde fungusun latent olarak bulunabilmesi, enfekteli materyallerin taşınması ile hastalığın yayılışında önemli bir etkiye sahiptir. Smith vd. (2000) tarafindan, tohum hareketliliğinin bu patojenin dünya çapındaki yayılışına en fazla katkıda bulunan faktör olduğu belirtilmiştir. Tohum ve kozalakların bu patojene karşı çok hassas olduğu (Peterson, 1977) ve bunların patojen tarafindan en fazla kolonize edilen bitki kısımları olduğu uzun yıllardır bilinmektedir (Munck vd., 2009; Santini vd., 2008; Smith vd., 2002). Fungus, sarıçam ve karaçam da dahil olmak üzere birçok çam türünün tohumunda tespit edilmiştir (Decourcelle vd., 2015; Smith vd., 2015; Vujanovic vd., 2000). Tohum enfeksiyonları, uzun mesafede (uluslararası ticaret ya da bölgeler arası tohum hareketliliği) patojenin yayılması ve hastalık epidemiyolojisinde kritik öneme sahiptir. Fungusla bulaşık tohumların kullanılması, patojenin özellikle fidanlıklara bulaşmasına yol açabilecek potansiyel bir araçtır (Smith vd., 2015)

Diplodia sapinea'nın sebep olduğu çam sürgün yanıklığ 1 hastalığı ülkemizde de çamların yaygın hastalıklarından biridir (Oskay vd., 2018b). Patojen ülkemizde Akdeniz Bölgesi'nden Batı Karadeniz'e, Marmara Bölgesi'nden Güney Doğu Anadolu'ya, tüm yerli çam türlerimiz (Pinus halepensis Mill, P. brutia Ten., P. nigra Arnold, P. sylvestris L., $P$. pinea L.) ile bazı egzotik çam türlerinde [Pinus radiata D. Don, P. brutia var. elderica (Medw.), P. pinaster Aiton, P. taeda L.] (Doğmuş-Lehtijärvi vd., 2007, 2014; Laz vd., 2018; Özkazanç ve Maden, 2013; Soylu vd., 2001; Sümer, 2000; Ünligil ve Ertaş, 1993; Yeltekin, 2015; Aday Kaya vd., 2019) ve Duglas Göknarı Göknarı [Pseudotsuga menziesii (Mirb.) Franco] ile Toros sedirinde (Cedrus libani A. Rich) rapor edilmiştir (Aday Kaya vd., 2014; Oskay vd., 2018a). Hastalık, kentsel alanlarda, park ve bahçelerdeki çamlarda da tespit edilmiştir (Oskay vd., 2018c; Ünal vd., 2018; Ünligil ve Ertaş, 1993). Bunların da ötesinde, D. sapinea'nın, ülkemizde çeşitli çam türlerine ait tohum bahçelerinde de önemli zararlara sebep olduğu bilinmektedir (Aday Kaya vd.,
2019; Doğmuş-Lehtijärvi vd., 2014). Patojenin, Kefken Orman İşletme Şefliği (Adapazarı) sınırları içerisinde bulunan karaçam ve sarıçam tohum bahçelerinde önemli oranda tahribata yol açtığı (Doğmuş-Lehtijärvi vd., 2014), yine aynı işletme şefliği sınırlarında yer alan $P$. radiata, $P$. pinaster ve $P$. menziesii tohum meşcerelerinde de oldukça yaygın ve önemli zararlara sebep olduğu tespit edilmiştir (Aday Kaya vd., 2019; Yeltekin, 2015). Bunlara ek olarak, Şanlı vd. (2010) tarafından da Balıkesir'de bir karaçam tohum bahçesinde de yoğun $D$. sapinea zararı tespit edilmiştir. Bununla birlikte, ülkemizde, bu patojenin çam tohumlarındaki varlığının ve tohumlar ya da kozalaklar aracılığı ile fidanlıklara ve orman alanlarına taşınma riskinin ortaya konulmasına yönelik bir çalışma bulunmamaktadır.

Orman Ağaçları ve Tohumları Islah Araştırma Enstitüsü Müdürlüğü (OATIAEM) (2021)'ne göre ülke genelinde 55 adet karaçam ve 21 adet sarıçam tohum bahçesi bulunmaktadır. Yüksek maliyetlerle kurulan bu tohum kaynakları, yeterli miktar ve kalitede tohum sağlanamaması durumda iptal edilebilmektedir. Bugüne kadar tesis edilen karaçam ve sarıçam tohum bahçelerinden sırasıyla 18 ve 7 adedi çeşitli sebeplerden ötürü iptal edilmiş durumdadır. İptal edilen bu bahçelerden bazılarında Diplodia sapinea'nın şiddetli zararı tespit edilmiştir (Aday-Kaya vd., 2019; Doğmuş-Lehtijärvi vd., 2014; Şanlı vd., 2010; Yeltekin, 2015). Fungusun tohum bahçelerinde tespit edilmiş olması bu patojenin, ülkemiz ormancılığı için tohum kaynağı görevi üstlenen tohum bahçelerinden toplanan kozalaklar ya da tohumlar aracılığ düşündürmektedir. Tohum bahçeleri, meşcereleri ve bu alanlardan toplanan tohumlarda bu patojenin bulunup bulunmadığının araştırılması, hem bu alanlarda hastalıkla mücadelede, hem de tohumlar aracılığı ile yayılmasının engellenmesinde oldukça önemlidir.

Bu çalışma, D. sapinea ile enfekteli olduğu bilinen iptal edilmiş bazı tohum bahçelerinden toplanan tohumlarda bu fungusun varlığının ve yoğunluğunun belirlenmesi amacı ile yürütülmüştür. Çalışmada, fungus izolasyonunda klasik yöntemlerden faydalanılmış, teşhisler moleküler yöntemlerle doğrulanmıştır.

\section{Materyal ve yöntem}

\subsection{Araştırmada kullanılan tohumların temini}

Tohumlar, Sakarya Orman Bölge Müdürlüğü, İzmitKefken işletme şefliği sınırında bulunan ve çeşitli sebeplerden ötürü kullanımı iptal edilen üç adet karaçam tohum bahçesi [Ulusal kayıt no (UK) 49, 52 ve 53] ile 1 adet sarıçam tohum bahçesinden (UK 92) toplanan kozalaklardan ekstrakte edilmiştir. Kozalaklar 2017 yılı Aralık ayında, ağaçlara çıkılarak her bir tohum bahçesinden en az 3 ağaçtan ve en az 10'ar kozalak olacak şekilde rastgele toplanmıştır. Çalışma kapsamında, iptal edilen tohum bahçelerinden temin edilen tohumlar yanında, kontrol grubu olarak, aktif durumdaki bir adet karaçam tohum bahçesi (Ulusal kayıt no 73) ve bir adet sarıçam tohum meşceresinden (Ulusal kayıt no 156) temin edilen tohumlar da kullanılmıştır. Buna göre, çalışma kapsamında, dördü iptal edilmiş, ikisi aktif durumda olmak üzere toplam altı farklı tohum kaynağından temin edilen tohumlar kullanılmıştır (Çizelge 1). Toplanan kozalaklar OATIAEM'e getirilerek müdürlük bünyesinde bulunan 1sıtmalı inkübatörlerde $45^{\circ} \mathrm{C}$ de 2 gün kurutulduktan sonra çıkarılmıştır. 


\subsection{Tohum kalite kontrol testleri}

Tohumlar temin edildikten sonra OATIAEM, Tohum Kalite Kontrol Laboratuvarında bindane ağırlıkları ve çimlendirme testleri ile tohum çimlenme yüzdeleri (ÇY) ve enerjileri (ÇE) belirlenmiştir. Her bir tohum kaynağına ait tohumların bindane ağırlığ 8 yinelemeli olarak 100'erli gruplar halinde rastgele seçilen tohumların elektronik hassas terazide tartıldıktan sonra, 8 yinelemenin ortalamasının alınıp 10 ile çarpılması sureti ile hesaplanmıştır (ISTA, 1996).

Tohumlarda çimlendirme testleri her bir tohum kaynağ 1 için 50 adet tohumda 4 yinelemeli olarak, Jacobsen çimlendirme havuzunda gerçekleştirilmiştir (6 tohum kaynağı x 50 tohum x 4 tekrar). Bunun için tohumlar spiralli filtre kağıtlarına birbirlerine değmeyecek şekilde dizilmiş ve $25^{\circ} \mathrm{C}$ ye ayarlanmış Jacobsen çimlendirme havuzlarına alınarak \%60-70 nem koşullarında çimlenmeye bırakılmıştır. Yedinci ve 28. günlerde yapılan değerlendirmelerde çimlenen tohumlar sayılmıştır. Kökçüğü, tohum boyunun 11,5 katı olan tohumlar çimlenmiş kabul edilmiştir. Çimlenme testleri sonrası çimlenme enerjisi 7. gün, çimlenme yüzdesi ise 28. gün sayım sonuçlarına göre, aşağıdaki denklemler (Denklem 1;2) yardımı ile hesaplanmıştır.

$$
\begin{aligned}
& \operatorname{CE}(\%)=\frac{\sum n i}{N} \times 100 \\
& \operatorname{CY}(\%)=(\%)=\frac{\sum n i i}{N} \times 100
\end{aligned}
$$

$$
\begin{array}{ll}
\text { ÇE }(\%) & \text { : Çimlenme enerjisi, } \\
n i & \text { : 7. gündeki çimlenme sayısı, } \\
\text { ÇY }(\%) & : \text { Çimlenme yüzdesi, } \\
n i i & : \text { 28. gündeki çimlenme sayısı, } \\
\mathrm{N} & : \text { toplam tohum sayısı }
\end{array}
$$

\subsection{Tohumlarda Diplodia sapinea enfeksiyonlarının tespiti}

Tohumlar, D. sapinea ile bulaşık olup olmadıklarını belirlemek amacı ile Bavendamm ortamına (BA; 20g Agar, $15 \mathrm{~g}$ Malt ektrakt, $5 \mathrm{~g}$ tannik asit, pH 5; Bavendamm, 1928) ekilmiştir (Decourcelle vd., 2015). Tohumlar besi ortamına ekim yapılmadan önce yüzey sterilizasyonuna tabi tutulmuştur. Yüzey sterilizasyonu için tohumlar önce $\% 75^{\prime}$ lik etanolde 30 saniye, ardından \%4'lük NaOCl'de 5 dakika bekletilmiş ve steril saf suda 5 dakika yıkanıp steril kurutma kağıtları arasında kurumaya bırakılmıştır. Tohumlar kuruduktan sonra içerisinde BA ortamı bulunan $90 \mathrm{~mm}$ çapındaki Petri kutularına, her birine en fazla 10 adet tohum olacak şekilde ekilmiştir. Petriler $20^{\circ} \mathrm{C}$ 'de inkübe edilmiş ve tohumlardan gelişen fungal koloniler, 3, 5, 10. günlerde sayılmış ve ardından izole edilmiştir. Fungal kolonilerin sayımı; i) fungal gelişim olmayan, ii) Diplodia sapineabenzeri koloniler (hızlı gelişen, başlangıçta beyaz daha sonra koyu gri renge dönen pamuğumsu havai misel gelişimi gösteren), iii) diğer funguslar şeklinde gerçekleştirilmiştir.

Tohumlarda $D$. sapinea enfeksiyon yoğunluğu ( $D$. sapinea kolonizasyonu), her bir tohum kaynağı için, üzerinde D. sapinea benzeri koloni gelişimi gözlemlenen tohumların yüzdesi (D. sapinea gelişimi görülen tohum adedi x100/ toplam tohum adedi) şeklinde hesaplanmıştır. Fungal gelişim görülmeyen ya da diğer funguslar tarafından kolonize edilen tohumların yüzdeleri de aynı şekilde hesaplanmıştır. Hesaplamalarda, tohum ekimini takip eden 10. günde yapılan koloni sayımları esas alınmıştır.

Tohumlara ek olarak, tohumların çıkarıldığı kozalaklarda da D. sapinea'nın varlığı morfolojik olarak araştırılmıştır. Bunun için, iptal edilmiş tohum bahçelerinden getirilen kozalaklardan tohum çıkarma işlemi tamamlandıktan

\begin{tabular}{|c|c|c|c|c|c|c|c|c|}
\hline $\begin{array}{c}\text { Ağaç } \\
\text { türü }\end{array}$ & $\begin{array}{c}\text { Tohum } \\
\text { kaynağ1 türü }\end{array}$ & $\begin{array}{c}\text { Kullanım } \\
\text { durumu }\end{array}$ & UK & Orijin & $\begin{array}{c}\text { Bölge } \\
\text { müdürlüğü }\end{array}$ & $\begin{array}{c}\text { İşletme } \\
\text { müdürlüğü }\end{array}$ & Şeflik & $\begin{array}{c}\text { Tesis } \\
\text { Y1li } \\
\end{array}$ \\
\hline \multirow{4}{*}{ Karaçam } & \multirow{4}{*}{$\begin{array}{l}\text { Tohum } \\
\text { bahçesi }\end{array}$} & & 49 & Alaçam-Gölcük & Sakarya & İzmit & Kefken & 1980 \\
\hline & & İptal edilmiş & 52 & Bayindir-Ovacık Arş. Ormanı & Sakarya & İzmit & Kefken & 1982 \\
\hline & & & 53 & Denizli-Kocabaş & Sakarya & İzmit & Kefken & 1983 \\
\hline & & Aktif & 73 & Nazilli-Sarıcaova & Muğla & Kemer & Akçay & 1990 \\
\hline \multirow{2}{*}{ Sarıçam } & $\begin{array}{l}\text { Tohum } \\
\text { bahçesi }\end{array}$ & İptal edilmiş & 92 & Daday-Sarıçam & Sakarya & İzmit & Kefken & 1982 \\
\hline & $\begin{array}{c}\text { Tohum } \\
\text { meşceresi }\end{array}$ & Aktif & 156 & Çamlıdere-Benliyayla & Sakarya & Çamlidere & Benliyayla & 1972 \\
\hline
\end{tabular}
kozalakların tümü, üzerinde $D$. sapinea'ya ait üreme yapıları (piknitler), bu yapıların tespit edilmesi durumunda fungusun karakteristik sporlarının varlığı bakımından stereomikroskop ve 1ş1k mikroskobu kullanılarak morfolojik olarak incelenmiştir.

Çizelge 1. Kullanılan tohumların tohum kaynaklarına ilişkin bilgiler 


\subsection{Tür teşhisinin doğrulanmast ve diğer fungusların} tanılanması

BA ortamında gelișen $D$. sapinea benzeri ve diğer funguslar olarak gruplandırılan fungal koloniler aseptik koşullarda içerisinde patates dekstroz agar (PDA) bulunan 60 $\mathrm{mm}$ çapındaki Petri kaplarına transfer edilerek saflaştırılmıştır.

Diplodia sapinea-benzeri izolatların tür teşhisinin doğrulanmasında ve diğer funguslara ait fungusların teşhisinde moleküler yöntemlerden faydalanılmıştır. Bunun için, her bir tohum kaynağına ait tohum grubundan izole edilen i) $D$. sapinea-benzeri izolatlardan 1-5 adet ii) diğer funguslara ait izolatlardan makroskopik karakteristikleri bakımından teşhisi yapılamayanlar seçilmiştir. Seçilen tüm izolatlardan ilk olarak DNA izolasyonu yapılmış, ardında ITS gen bölgeleri çoğaltılarak dizilemeye gönderilmiştir. $D$. sapinea-benzeri izolatların tür tanısının doğrulanmasında, ITS dizilemesine ek olarak türe özgü primerlerle geleneksel PCR da yapılmıştır. Kullanılan yöntemlerin detayları aşağıda verilmiştir.

Fungal izolatlar, üzerinde selofan membran bulunan PDA besi ortamında 1-2 hafta boyunca $24{ }^{\circ} \mathrm{C}$ 'de geliştirilmiş, gelişen miseller bistüri yardımıyla selofandan kazınarak, steril porselen havanlar içerisinde sıvı azot yardımı ile toz haline getirilmiştir. Her bir fungal izolata ait DNA, Nucleospin Plant II miniprep (Macherey-Nagel, Hoerdt, France) kiti kullanılarak, üretici firmanın talimatları doğrultusunda ekstrakte edilmiştir.

PCR amplifikasyonlarında ITS rRNA bölgesi üniversal primer seti ITS1 (5'-TCCGTAGGTGAACCTGCGG-3') ve ITS4 (5'-TCCTCCGCTTATTGATATGC-3') kullanılmıştır (White vd., 1990). Elde edilen PCR ürünleri $\% 1$ 'lik agaroz jel üzerinde etidiyum bromid ile boyanarak yürütülmüş ve bant oluşumu görülen PCR ürünleri, ticari bir firmaya (SENTEBİOLAB, Ankara) gönderilerek dizilenmiştir. İzolatlara ait DNA dizilerinin, gen Bankasında yer alan diziler ile benzerliklerinin karşılaştırılmasında NCBI (National Center for Biotechnology Information) web sitesinde yer alan nucleotideblastn programı kullanılmıştır.

D. sapinea benzeri izolatların tür teşhisinin doğrulanmasında Smith ve Stanosz (2006) tarafindan geliştirilen türe özgü primer çiftleri DpF (5, CTTATA TATCAAACTAATGTTTGCA 3') ve BotR (5' GCTTACACTTTCATTTATAGACC '3) kullanılmıştır. PCR amplifikasyonu Smith ve Stanosz (2006)'da belirtilen reaksiyon karışımı bileşenleri ve döngü koşullarında gerçekleştirilmiştir. PCR ürünleri \%2'lik agaroz jelde ayrılarak etidiyum bromid ile boyanarak jel görüntüleme sisteminde fotoğraflanmış, jel üzerinde 650bp'lik bantların bulunması durumunda izolatın tanısı $D$. sapinea olarak doğrulanmıştır. PCR reaksiyonlarında negatif (yalnızca steril saf su içeren) ve pozitif (referans D. sapinea izolatının DNA'sı) kontrol kullanılmıştır.

\section{Bulgular}

\subsection{Tohum kalitesi}

İptal edilmiş karaçam tohum bahçelerinden (TB49, TB52 ve TB53) temin edilen tohumların bindane ağırlıkları 8,0 $10,0 \mathrm{~g}$, çimlenme enerjileri \%1,0-2,0 ve çimlenme yüzdeleri \%3,0-5,0 arasında ölçülürken, aktif durumdaki karaçam tohum bahçesinden (TB73) temin edilen tohumların bindane ağırlığ $21,1 \mathrm{~g}$, çimlenme enerjileri \%77 ve çimlenme yüzdeleri \%79 olarak belirlenmiştir (Şekil 1a; Şekil 1b). Sarıçam tohumlarında bu değerler iptal edilmiş tohum bahçesine ait tohumlar (TB92) için sırası ile; 4,1g, \%2,0 ve $\% 1,0$, aktif tohum meşceresine ait tohumlar (TM156) için 7,5 g, \%15,0, \%32,0’dir (Şekil 1)

\subsection{Tohumlarda D. sapinea enfeksiyon yoğunluğu}

Dördü iptal edilmiş tohum bahçesi olmak üzere, altı farklı tohum kaynağından 70 ila 200 arasında, toplam 1023 adet tohum, $D$. sapinea ile bulaşık olup olmadıklarını belirlemek amacı ile BA ortamına ekilmiş, tohumlardan gelişen $D$. sapinea kolonileri, fungusun enfeksiyon yoğunluğunu belirlemek amacı ile sayılmıştır. Buna göre bu çalışma kapsaminda iptal edilmiş karaçam ve sarıçam tohum bahçesinden gelen 625 tohumun (sırasıly 555 ve 70 adet) \%70'inin (sırasıyla \%72 ve 57) D. sapinea ile bulaşık olduğu tespit edilmiştir (Şekil 2, Çizelge 3). İptal edilmiş tohum bahçelerinde en yüksek $D$. sapinea enfeksiyonu TB53 nolu karaçam tohum bahçesinde (\%86), en düşük enfeksiyon yoğunluğu TB92 sarıçam tohum bahçesinde belirlenmiştir (\%57; Şekil 2). Buna karşılık, aktif tohum kaynaklarından sadece TM156 nolu tohum meşceresinde tek bir tohumdan $(\% 0,50)$ D. sapinea izole edilmiş, karaçam tohum bahçesinde (TB73) ise patojen tespit edilmemiştir (Şekil 2, Çizelge 3).

Kozalaklar üzerinde yapılan incelemeler sonucunda; TB49, TB52, TB53 ve TB92 nolu iptal edilmiş tohum bahçelerinden toplanan kozalakların tümünde fungusun üreme yapıları tespit edilmiştir.
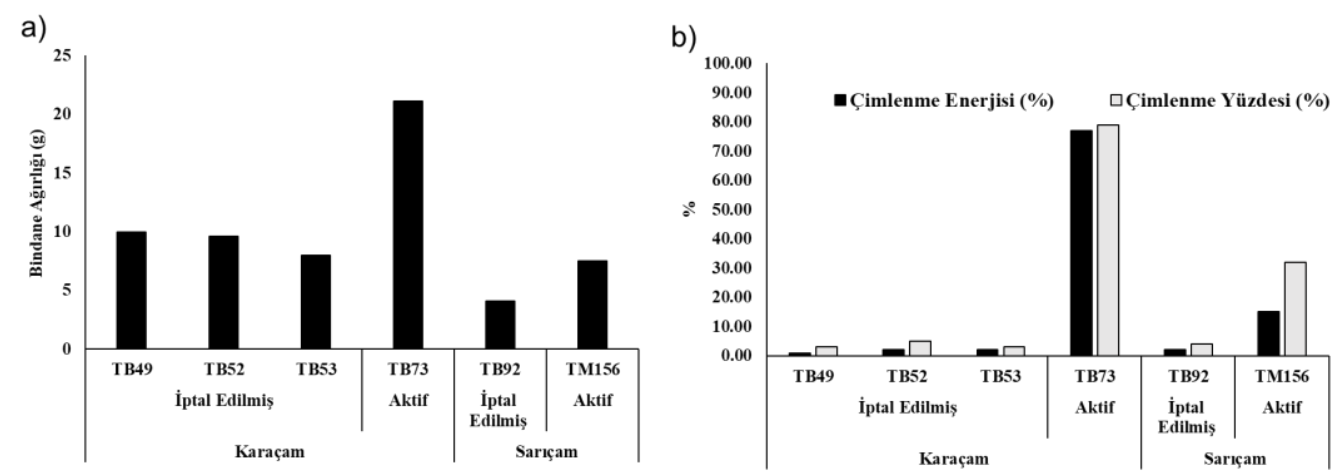

Şekil 1. İptal edilmiş ve aktif durumdaki tohum kaynaklarından temin edilen tohumlarda a) bindane ağırlıkları b) çimlenme enerjisi ve yüzdesi (\%) 


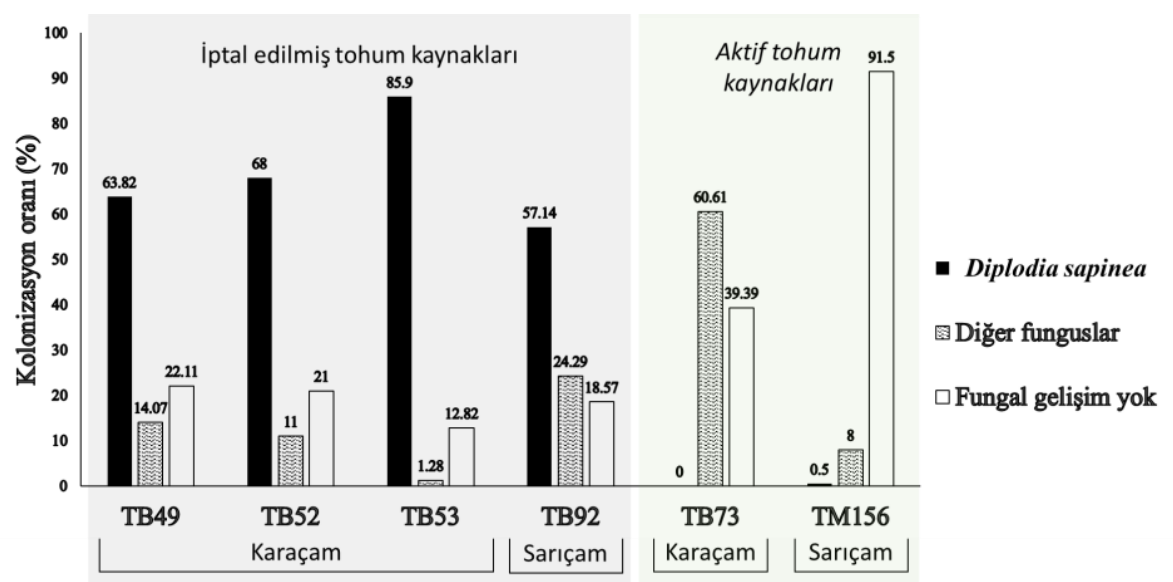

Şekil 2. İptal edilmiş ve aktif durumdaki tohum kaynaklarından temin edilen tohumlarda Diplodia sapinea ve diğer fungusların kolonizasyon oranları (\%)

\subsection{Diplodia sapinea tür teşhisinin doğrulanması}

Tohumlarda bir (TM156) ila 136 (TB52) arasında olmak üzere $D$. sapinea-benzeri koloni gelişimi gözlemlenmiştir. TM156 tohumlarında sadece bir $D$. sapinea-benzeri izolat elde edilmiş, TB73'de ise $D$. sapinea-benzeri koloni gelişimi görülmemiştir (Çizelge 2). Tohumlardan gelişen bu koloniler saflaştırılmış ve D. sapinea-benzeri toplam 15 izolat (TB49TB53 üçer izolat, TB92 beş izolat ve TM 156 bir izolat; Çizelge 2, Çizelge 3) moleküler tanı için değerlendirmeye alınmıştır. D. sapinea'ya özgü primerler ile test edilen tüm izolatlar pozitif sonuç vermiş (Çizelge 2). Buna ek olarak, üç izolatın; FO2018TB49AT15, FO2018TB92AT10 ve FO2018TM156AT13, ITS dizileri, genbankasında yer alan Diplodia sapinea tip materyali (CBS 393.84, GenBank kayit no: NR 152452.1) ile karşılaştırılmış, izolatlar bu referans materyalle \%99 (FO2018TB49AT15) ve \%100 (FO2018TB92AT10 ve FO2018TM156AT13) benzerlik göstermiştir (Çizelge 2). Buna göre, tohumlardan gelişen ve D. sapinea benzeri olarak gruplandırılan tüm izolatların tanısı D. sapinea olarak doğrulanmıştır.

\subsection{Tohumlardan izole edilen diğer funguslar}

Tüm tohumlarda, 13 farklı cinste fungus teşhis edilmiştir. Bunlara ek olarak, tohumlarda teşhisi yapılamayan mayalar ve bazı funguslar da tespit edilmiştir (Çizelge 3). Alternaria spp., Sydowia polyspora (Bref. \& Tavel) E. Müll., Mucor spp., tüm tohum kaynaklarından gelen tohumlarda tespit edilen yaygin funguslardır. Nigrospora sp., Trichoderma spp. ve Trichothecium roseum (Pers.) Link, hem iptal edilmiş hem aktif durumdaki tohum kaynaklarına ait tohumlarda tespit edilen funguslardır. Tek bir tohum kaynağında tespit edilen funguslar ise yoğunlukları bakımından sırasıyla Chaetomium sp. (TB73), Scytalidium sp. (TB73), Fusarium sp. (TB49), Xylaria sp. (TB49), Clonostachys rosea (Link) Schroers, Samuels, Seifert \& W. Gams (TB92)'dir.

Tohumlarda $D$. sapinea dışındaki diğer fungusların kolonizasyon oranları iptal edilen tohum bahçelerinde $\% 11,04(\% 1.28$ - 24,29), aktif durumdaki tohum bahçelerinde ise \%34,17 (\%8,00 - 60,61) olarak belirlenmiştir (Şekil 2, Çizelge 3). İptal edilmiş tohum bahçeleri arasından diğer fungusların en yoğun tespit edildiği tohumlar TB92 no'lu sarıçam tohum bahçesi tohumları $(\% 24,29)$ olup, en yaygın fungus \% 7,14 oranında Sydowia polyspora olarak teşhis edilmiş, bunu Trichoderma spp. (\%4,29) takip etmiştir. Diğer fungusların kolonizasyon oranının en düşük olduğu tohum kaynağ1 ise TB53 $(\% 1,28)$ olup bu tohumlarda $D$. sapinea dışında yalnızca Alternaria sp1. ve Trichothecium roseum izole edilmiştir (Şekil 2, Çizelge 3). D. sapinea enfeksiyonun tespit edilmediği TB73 nolu tohum bahçesinde fungal kolonizasyon oran $\%$ \%6,61'dir. Bu tohumlarda en yaygın funguslar arasında sırasıyla, teşhisi yapılmayan mayalar (\%15,15), Sydowia polyspora, Alternaria spp., Chaetomium sp., Aspergillus spp., Nigrospora sp., Penicillium spp., Scytalidium sp., Mucor sp. yer almıştır (Çizelge 3). 
Çizelge 2. Farklı moleküler yöntemlerle tanısı kesinleştirilen Diplodia sapinea izolatları (-: ilgili işlem bu izolat için yapılmamıştır; +: izolatın tanısı ilgili yöntemle Diplodia sapinea olarak kesinleştirilmiştir; *:izolatın Genbankasında yer alan Diplodia sapinea tip materyali NR_152452.1 ile benzerlik oranı parantez içinde verilmiştir)

\begin{tabular}{|c|c|c|c|c|c|c|}
\hline \multirow{2}{*}{ Ağaç türü } & \multirow{2}{*}{ Tohum kaynağı türü } & \multirow{2}{*}{ Kullanım durumu } & \multirow{2}{*}{ Uk_No } & \multirow{2}{*}{ İzolat adı } & \multicolumn{2}{|c|}{ Doğrulama yöntemi } \\
\hline & & & & & ITS dizileme* $^{*}$ & Türe özgü cPCR \\
\hline \multirow{10}{*}{ Karaçam } & \multirow{10}{*}{ Tohum Bahçesi } & \multirow{9}{*}{ İptal Edilmiş } & \multirow{3}{*}{ TB49 } & FO2018TB49AT1 & - & + \\
\hline & & & & FO2018TB49AT2 & - & + \\
\hline & & & & FO2018TB49AT15 & $+(\% 99)$ & + \\
\hline & & & \multirow{3}{*}{ TB52 } & FO2018TB52AT4 & - & + \\
\hline & & & & FO2018TB52AT5 & - & + \\
\hline & & & & FO2018TB52AT6 & - & + \\
\hline & & & \multirow{3}{*}{ TB53 } & FO2018TB53AT7 & - & + \\
\hline & & & & FO2018TB53AT8 & - & + \\
\hline & & & & FO2018TB53AT9 & - & + \\
\hline & & Aktif & TB73 & Izole edilmedi & & \\
\hline \multirow{6}{*}{ Sarıçam } & \multirow{5}{*}{ Tohum Bahçesi } & \multirow{5}{*}{ İptal Edilmiş } & \multirow{5}{*}{ TB92 } & FO2018TB92TRDIP90 & - & + \\
\hline & & & & FO2018TB92TRDIP91 & - & + \\
\hline & & & & FO2018TB92AT10 & $+(\% 100)$ & + \\
\hline & & & & FO2018TB92AT11 & - & + \\
\hline & & & & FO2018TB92AT12 & - & + \\
\hline & Tohum Meşceresi & Aktif & TM156 & FO2018TM156AT13 & $+(\% 100)$ & + \\
\hline
\end{tabular}

Çizelge 3. Tohumlarda tespit edilen diğer funguslar ve kolonizasyon oranları (\%)

\begin{tabular}{|c|c|c|c|c|c|c|c|c|}
\hline \multirow{2}{*}{$\begin{array}{r}\text { Kullanım durumu } \\
\text { Ağaç türü }\end{array}$} & \multicolumn{5}{|c|}{ İptal edilmiş } & \multicolumn{3}{|c|}{ Aktif } \\
\hline & & Karaçam & & Sarıçam & & Karaçam & Sarıçam & \\
\hline Tohum kaynağı & TB49 & TB52 & TB53 & TB92 & Ortalama & ТВ73 & TM156 & Ortalama \\
\hline Fungi & \multicolumn{8}{|c|}{ Kolonizasyon (\%) } \\
\hline Diplodia sapinea ${ }^{* a}$ & 63,82 & 68,00 & 85,90 & 57,14 & 69,92 & 0 & 0,50 & 0,25 \\
\hline \multicolumn{9}{|l|}{ Diğer Funguslar } \\
\hline Alternaria spp. & 4,02 & 4,00 & 0,64 & 1,43 & 2,88 & 9,60 & 1,00 & 9,80 \\
\hline Alternaria $\mathrm{sp} 1$ & 0,50 & 0,50 & 0,64 & 1,43 & 0,64 & 2,53 & 1,00 & 1,76 \\
\hline Alternaria sp2 & 0 & 0 & 0 & 0 & 0 & 3,03 & 0 & 1,51 \\
\hline Alternaria sp3 & 2,01 & 1,50 & 0 & 0 & 1,12 & 4,04 & 0 & 2,01 \\
\hline Alternaria sp4 & 1,51 & 2,00 & 0 & 0 & 1,12 & 0 & 0 & 0 \\
\hline Aspergillus spp. & 0 & 0 & 0 & 0 & 0 & 3,54 & 0,50 & 2,01 \\
\hline Aspergillus sp1 & 0 & 0 & 0 & 0 & 0 & 2,02 & 0,50 & 1,26 \\
\hline Aspergillus sp2 & 0 & 0 & 0 & 0 & 0 & 1,52 & 0 & 0,75 \\
\hline Aspergillus sp3 & 0 & 0 & 0 & 0 & 0 & 0 & 0 & 0 \\
\hline Chaetomium sp. & 0 & 0 & 0 & 0 & 0 & 5,56 & 0 & 2,76 \\
\hline Clonostachys rosea & 0 & 0 & 0 & 1,43 & 0,16 & 0 & 0 & 0 \\
\hline Fusarium sp. & 1,51 & 0 & 0 & 0 & 0,48 & 0 & 0 & 0 \\
\hline Mucor spp. & 1,01 & 1,00 & 0 & 2,86 & 0,96 & 2,02 & 0,50 & 1,26 \\
\hline Mucor sp1. & 0 & 0 & 0 & 2,86 & 0,32 & 1,52 & 0 & 0,75 \\
\hline Mucor sp2. & 1,01 & 1,00 & 0 & 0 & 0,64 & 0,51 & 0,50 & 0,50 \\
\hline Nigrospora sp. ${ }^{* \mathrm{~b}}$ & 0 & 2,00 & 0 & 1,43 & 0,8 & 3,03 & 0 & 1,51 \\
\hline Penicillium spp. & 2,51 & 2,00 & 0 & 2,86 & 1,76 & 3,54 & 1,00 & 2,26 \\
\hline Scytalidium $\mathrm{sp}^{*_{\mathrm{c}}}$ & 0 & 0 & 0 & 0 & 0 & 2,53 & 0 & 1,26 \\
\hline Sydowia polyspora & 3,52 & 1,50 & 0 & 7,14 & 2,4 & 9,60 & 1,50 & 5,53 \\
\hline Trichoderma spp. & 0 & 0 & 0 & 4,29 & 0,48 & 1,52 & 1,00 & 1,26 \\
\hline Trichothecium roseum & 0 & 0 & 0,64 & 0 & 0,16 & 0,51 & 0 & 0,25 \\
\hline Xylaria sp. ${ }^{* \mathrm{~d}}$ & 0,50 & 0 & 0 & 0 & 0,16 & 0 & 0 & 0 \\
\hline Teşhis edilemeyen funguslar & 1,00 & 0,50 & 0 & 2,86 & 0,80 & 19,19 & 2,50 & 10,81 \\
\hline Diğer funguslar toplam kolonizasyon & 14,07 & 11,00 & 1,28 & 24,29 & 11,04 & 60,61 & 8,00 & 34,17 \\
\hline
\end{tabular}




\section{Tartışma}

Doğmuş-Lehtijärvi vd. (2014), TB52, TB92 ve TB93 nolu iptal edilmiş tohum bahçelerinde geriye doğru ölüm ve sürgün yanıklığı simptomlarından Diplodia sapinea'nın sorumlu olduğunu ortaya koymuş, bu tohum bahçelerinde fungusun zarar şiddetini sırasıyla \%59, 34 ve 24 olarak tespit etmiştir. Bununla birlikte giderek artan tohum kayıplarından $\mathrm{da}$ bu fungusun sorumlu olabileceğini belirtmişlerdir. $\mathrm{Bu}$ çalışmaya ek olarak, 49 no'lu karaçam tohum bahçesinin de içinde yer aldığı çam plantasyonlarında da $D$. sapinea tespit edilmiştir (Aday-Kaya vd., 2019; Yeltekin, 2015). Ancak söz konusu çalışmalar kapsamında $D$. sapinea'nın tohumlardaki varlığı ve tohum kayıpları ile ilişkisi araştırılmamıştır. Bu çalışmamızda, iptal edilmiş tohum bahçelerinden temin edilen tohumların tümünde $D$. sapinea tespit edilmiştir. $\mathrm{Bu}$ çalışma ile ülkemizde $D$. sapinea belirtilerinin görüldüğü tohum bahçelerinde, fungusun tohumları da enfekte edebildiği ilk kez ortaya konulmuştur.

Karaçam (TB49, TB52 ve TB53) ve sarıçam (TB92) tohumlarında $D$. sapinea enfeksiyon oranı sirasiyla $\% 64,68$, 86 ve 57 olarak belirlenmiştir. Diplodia sapinea dünya çapında birçok çam türüne ait tohumlarda tespit edilmiştir (Bihon vd., 2011; Cleary vd., 2019; Decourcelle vd., 2015; Fraedrich vd., 1994; Rees ve Webber, 1988; Romero, 1997; Smith vd., 2002; Smith vd., 1996; Vujanovic vd., 2000; Zakaullah, 2000). Bununla birlikte bu çalışmaların çoğunda D. sapinea ile bulaşık tohum oranları nispeten düşüktür. Örneğin Vujanovic vd. (2000) Kanada'da bir arboretumda çeşitli çam türlerinin tohumlarında fungal enfeksiyonları araştırdığ1 çalışmasında, çamlarda $D$. sapinea enfeksiyon oranını ortalama \%4 civarında bulmuştur. Bihon vd. (2011), Güney Afrika'da yaptığı çalışmasında $P$. radiata tohumlarında $D$. sapinea enfeksiyon oranın $\% 2$ olarak tespit ederken, $P$. patula tohumlarindan bu fungusun izole edilmediğini bildirmiştir. Smith vd. (2015), yüzey sterilizasyonu yapılmış ya da yapılmamış Pinus resinosa ve $P$. banksiana tohumlarında $D$. sapinea enfeksiyon oranlarını $\% 0-4,7$ arasında tespit etmişlerdir. Diğer taraftan bazı çalışmalarda ise nispeten daha yüksek oranlarda $D$. sapinea enfeksiyonları tespit edilmiştir. Örneğin, Smith vd. (2002), yüzey sterilizasyonu yapılmamış $P$. patula tohumlarında $D$. sapinea enfeksiyon oranını \%23 olarak belirlemiştir. Decourcelle vd. (2015), şiddetli D. sapinea enfeksiyon belirtileri gösteren bir çam plantasyonundan toplanan tohumlar ile, daha önceden $D$. sapinea'nın varlığının tespit edilmediği sağlıklı görünen bir meşcereden toplanan tohumlarda fungusun yoğunluğunu sirasıyla $\% 38$ ve $\% 57$ olarak tespit etmişlerdir. Enfeksiyon oranlarının geniş oranda çeşitlilik göstermesinde, araştırmalarda kullanılan yöntemlerin önemli bir etkisi olabilir (Decourcelle vd., 2015; Smith vd., 2015). Nitekim Decourcelle vd. (2015), çalışmasında enfeksiyon oranının yüksek bulunmasının, fungus izolasyonunda seçici bir ortam olarak Bavendamm ortamının kullanımından kaynaklandığını, diğer çalışmalarda yaygın olarak tercih edilen PDA gibi genel besi ortamlarında aynı tohum partisine ait örneklerde bu fungusun izolasyon oranının \%17 olduğunu, Blodgett ve Swart ortamlarında ise tohumlardan fungusun izole edilemediğini bildirmişlerdir. Bu çalışmamızda da Decourcelle vd. (2015)'de olduğu gibi Bavendamm ortamı kullanılmıştır. Buna göre bu ortamın karaçam ve sarıçam tohumlarında bu fungusun seçici izolasyonu için etkili bir ortam olduğu da belirlenmiştir.
Çalışmamızda iptal edilmiş karaçam ve sarıçam tohum bahçelerinden temin edilen tohumların bindane ağırlıklarının normalden çok daha düşük olduğu (sırasıyla ortalama 9,2 ve $4,1 \mathrm{~g}$ ), ayrıca çimlenme yüzde ve enerjilerinin \% 5'in altında olduğu tespit edilmiştir. Sağlıklı karaçamlarda bindane ağırlığı ortalama $22,5 \mathrm{~g}$, sarıçam tohumlarında ise 9,6g'dır (Gezer ve Yücedağ, 2006). Ülkemizde yapılan birçok çalışmada karaçam ve sarıçam tohumlarının bindane ağırlıklarının tohum kaynağına göre yüksek varyasyon gösterebildiği belirlenmiştir. Örneğin Deligöz ve Gezer (2005), tohum meşcereleri, klonal tohum bahçeleri ve plantasyonlarından topladıkları karaçam tohumlarının bindane ağırlıklarının 18-27g arasında olduğunu bildirmiştir. Söz konusu çalışmadaki yüksek varyasyona rağmen, bizim çalışmamızda karaçam tohumlarının bindane ağırlığı bu aralığın altındadır. Bu çalışmamızda iptal edilmiş üç karaçam tohum bahçesine ait tohumların çimlenme yüzdeleri ortalama $\% 4$ olup, bu tohumların \%64, 68 ve 86 'sinın $D$. sapinea tarafından kolonize edildiği tespit edilmiştir. D. sapinea'nın tohum çürüklüğüne sebep olduğu, tohumların çimlenme enerjisini ve yüzdesini önemli oranda düşürebildiği bilinmektedir. Rees ve Webber (1988), D. sapinea ile yapay olarak inokule edilen çam tohumlarında çimlenme yüzdesinin inokule edilmeyen tohumlara kıyasla \%20 azaldığını tespit etmiştir. Başka bir çalışmada Bihon vd. (2011) de yapay olarak inokule edilen çam tohumlarında çimlenme yüzdesinin kontrole göre \%38 azaldığını bildirmiştir. Buna ek olarak Rees ve Webber (1988) bazı $D$. sapinea izolatlarının, bazı çam türlerine ait 14-20 günlük fideciklerin \%98'inin ölümüne yol açabildiğini de ortaya koymuşlardır. Bu bilgiler ışığında, çalışmamızda kullanılan tohumların bindane ağırlıklarının ve çimlenme özelliklerinin azalmasında bu fungusun önemli bir rolünün olduğu ileri sürülebilir.

$\mathrm{Bu}$ çalışmamızda kullanılan tohumlar, $45^{\circ} \mathrm{C}$ 'de etüvde 2 gün bekletilen kozalaklardan çıkarılmış ve fungal izolasyon öncesinde yüzey sterilizasyonuna tabi tutulmuştur. Buna rağmen tohumlarda ortalama $\% 70$ gibi yüksek oranda $D$. sapinea tespit edilmiştir. Decourcelle vd. (2015) $40{ }^{\circ} \mathrm{C}$ 'de 1 saat tutulan kozalaklardan çıkarılan $P$. nigra subsp. laricio tohumlarında enfeksiyon oranının $35^{\circ} \mathrm{C}$ 'de 10 gün bekletilen ya da hiç isı muamelesi görmeyen tohumlara kıyasla daha düşük olduğunu belirlemiştir. Diğer taraftan Iturritxa vd. (2011), $P$. radiata tohumlarında, yüzey sterilizasyonunun $D$. sapinea ve Fusarium circinatum için engelleyici olmadığını, ancak tohum çıkarma işlemi sırasında $55^{\circ} \mathrm{C}$ 'de 8 saat ya da daha uzun süre bekletilen kozalaklardan çıkarılan tohumlarda her iki fungusun da tohum yüzeyinden ve endosperminden \%100'e kadar elemine edilebildiğini ortaya koymuşlardır.

$\mathrm{Bu}$ çalışmamızda, tohumların yanı sıra, iptal edilmiş tohum bahçelerinden temin edilen kozalakların tümünde bol miktarda $D$. sapinea piknidi tespit edilmiştir. Fungus, ölü sürgünler, ibreler ve kozalaklar üzerinde üreme yapıları oluşturur ve buradan salınan sporlar ile kısa mesafelere, örneğin aynı meşcere içinde ya da civar meşcerelere yayılır (Capretti vd., 2013). Özellikle kozalaklar üzerinde fungusun bol miktarda üreme yapısı oluşturabilmesi ve bu üreme yapılarında üretilen sporların uzun süre canlılığını koruyabilmesi, hastalığın yeni bireylere bulaşmasında ve yayılmasında kritik bir role sahiptir (Munck vd., 2009; Santini vd., 2008; Smith vd., 2002). Örneğin Smith vd. (2002), genç $P$. patula sürgünlerinin, ağaçlarda asılı bulunan kozalaklardan yayılan sporlar aracılığı ile enfekte edildiğini ortaya koymuştur. Bu sebeple birçok çalışmada, hastalığın 
belirli bir alandaki yoğunluğunun ve yayılma riskinin belirlenmesinde fungusun kozalaklardaki yoğunluğunun ve inokulum miktarının araştırıldığı görülür. Örneğin İtalya'da yapılan bazı çalışmalarda fistık çamı kozalaklarının $\% 74$ ve \%80'inin D. sapinea ile enfekteli olduğu belirlenmiştir (Feducci vd., 2009; Santini vd., 2008). Amerika'da yapılan başka bir araştırmada ise iki farklı çam türünde $D$. sapinea üreme yapısı bulunan kozalak oranlarının \%37-95 arasında olduğu belirlenmiştir (Munck vd., 2009). Ülkemizde yapılan bir araştırmada, Aday-Kaya vd. (2019) sarıçam ve karaçam kozalaklarında $D$. sapinea bulunma oranlarını sırasıyla $\% 81$ ve 88 olarak bildirmiş, bu kozalaklardaki inokulum miktarını ise yine sırasıyla $1.3 \times 10^{6}$ ve $1.1 \times 10^{6}$ olarak belirlemiştir.

$\mathrm{Bu}$ çalışma sonucunda karaçam ve sarıçam tohumlarında, D. sapinea'ya ek olarak Sydowia polyspora gibi diğer patojenik türler de tespit edilmiştir. Tohumlarda tespit edilen diğer funguslar; Penicillium spp., Mucor spp., Aspergillus spp., Alternaria spp., Ulocladium sp., Chaetomium sp., Trichoderma spp., Fusarium sp., Xylaria sp., Nigrospora sp.'dir. Ülkemizde, orman ağaçlarının tohumlarında görülen fungusların tespitine yönelik sınırlı sayıda araştırma bulunmaktadır (Akıllı, 2004; Akıllı ve Katırcioğlu, 2006; Argun vd., 2014; Velioğlu, 2001). Velioğlu (2001), bazı iğne yapraklı ağaç türleri ve gladiçyaya ait tohumlarda çimlendirme testleri sırasında gözlemlenen fungusları, Akıllı ve Katırcıŏlu (2006) karaçam, kızılçam ve sarıçam tohum meşcerelerinden toplanmış tohumların fungal bulaşıklığını belirlemiştir. Her iki çalışma sonucunda tespit edilen fungusların genelde kozalak hasat ve tohum depolama safhalarında bulaşan türler olduğu belirtilmiştir. Diğer taraftan Argun vd. (2014) tarafindan, karaçam tohum bahçeleri ve meşcerelerinden toplanan tohumlarda bulunan funguslar ve bunların fidanlardaki patojenisiteleri araştırılmıştır. Araştırmada, belirlenen fungusların çoğunluğunun tohumlarda çürümeye ve çimlenmeyi engelleyici etkileri olan küf fungusları olduğu belirlenmiş, çalışma sonucunda yaygın küf funguslarından Penicillium türlerinin fidanlarda ölüme sebep olduğu, ayrıca Fusarium oxysporum ve Alternaria alternata'nın fidanlarda ölüme ve gelişme geriliğine sebep olduğu tespit edilmiştir. Ülkemizde yapılan diğer çalışmalar ile karşılaştırıldığında, bu çalışma ile birlikte Diplodia sapinea, Sydowia polyspora, Xylaria sp. ve Nigrospora sp.'nin çam tohumlarından ilk defa izole edildiği anlaşılmaktadır. Bununla birlikte, Cleary vd. (2019), İsveç, Portekiz, İngiltere, ABD ve Türkiye'den çeşitli çam türlerine ait tohumların fungal topluluklarını yüksek verimli DNA dizilemeye dayanan metabarkodlama yaklaşımı ile moleküler olarak belirledikleri çalışmalarında, Türkiye'yi temsil eden tohum örneklerinde D. sapinea, Sydowia polyspora ve Xylaria sp. moleküler olarak tespit edilmiştir. Diğer taraftan, söz konusu çalışmada, Türkiye'den temin edilen $P$. pinaster, $P$. nigra subsp. pallasiana, $P$. brutia, $P$. sylvestris, $P$. radiata, $P$. halepensis ve $P$. pinea tohumları arasindan $P$. sylvestris tohumlarında bu üç fungus tespit edilmemiştir. Buna göre bu çalışmada, ülkemizde sarıçam tohumlarında, $D$. sapinea ve $S$. polyspora ilk kez belirlenmiştir.

\section{Sonuç}

Tohum ve kozalak zararlıları ile patojenik funguslar, iğne yapraklı türlerde kozalak ve tohum kayıplarından sorumlu başlıca biyotik faktörlerdir. Ülkemizde çeşitli çam türleri ile kurulan, ana amacı sağlıklı ve yüksek verimli tohum üretimi olan tohum islah tesislerinde kozalak ve tohum üretimini ve sağlığını önemli derecede sınırlandıran zararlılar üzerine bazı araştırmalar bulunmakla birlikte (Aslan, 2018; Can, 2003; Özçankaya ve Can, 2006), kozalak ve tohumlarda, hastalık etmeni fungusların araştırıldığı çalışmalar yok denecek kadar azdır. Bununla birlikte ülkemizde orman ağacı tohumları ile ilişkili fungusların araştırıldığı sınırlı sayıdaki çalışmada, tohumla taşınan hastalıklar ve bu bağlamda iç ve dış karantinada tohum patojenlerinin tespitinin önemi vurgulanmış olsa da (Akıllı, 2004; Akıllı ve Katırcıŏglu, 2006; Velioğlu, 2001) bu çalışmalarda tohumların genel mikobiotasının belirlenmesi hedeflenmiş ve özellikle hasat ve tohum depolama safhalarında bulaşan saprobik fungal türler tespit edilerek tohum sağlığı hususunda yalnızca tohumu etkileyen fungusların, diğer bir deyişle hasat ve depolama koşullarının uygunluğu üzerinde durulmuştur (Ak1llı ve Katırcıoğlu, 2006; Argun vd., 2014; Velioğlu, 2001).

Günümüzde, önemli birçok zararlı organizmanın ulusal ya da uluslararası yayılışında bulaşık tohumların ciddi boyutlarda risk teşkil ettiği bilinmekte ve canlı bitki ve tohum ticareti hastalık etmenlerinin uzun mesafelerde ülkeler ve kıtalar arasında taşınmasında önemli bir yol olarak kabul edilmektedir (Cleary vd., 2019; Franic vd., 2019; Santini vd., 2013). Dolayısıyla, tohumla taşınan patojenlerin tespiti, hastalıkların yeni alanlara taşınmasının ya da geniş alanlara yayılmasının engellenmesinde oldukça önemlidir. Diplodia sapinea tohumla taşınan önemli bir orman patojenidir ve bu patojenin tohumlarda tespiti, tohumların taşınması (fidanlık ve orman alanlarına) ya da ticareti (uluslararası ya da ülke içinde) ile hastalığın yayılmasının engellenmesinde kritiktir. $\mathrm{Bu}$ çalışmamızda, D. sapinea karaçam ve sarıçam tohumlarında yüksek bulaşıklık oranları ile tespit edilmiştir. Bununla birlikte çalışmada kontrol olarak değerlendirmeye alınan sağlıklı bir sarıçam tohum meşceresine ait tohumlarda da $\% 0,5$ gibi düşük bir oranda da olsa $D$. sapinea tespit edilmiştir. Fungusun belirti göstermeyen orman alanlarında ve bu tür alanlardan toplanan tohumlarda da bulunabileceği bilinmektedir. Örneğin Decourcelle vd. (2015), hastalık belirtisi göstermeyen ağaçlardan toplanan tohumlarda, belirti gösteren bir orman alanından toplanan tohumlara kıyasla daha yüksek oranda $D$. sapinea enfeksiyonu tespit etmiştir. $\mathrm{Bu}$ durum ülkemizde de sağlıklı ya da sağlıksız tohum kaynaklarından toplanacak tohumlarda bu fungusun bulunabileceğine, dolayısıyla, enfekteli tohumların taşınması ile hastalığın yayılabileceğine işaret etmektedir. Nitekim Smith vd. (2015) de, fidanlıklarda çok yüksek miktarlarda tohum kullanıldığı göz önünde bulundurulduğunda, enfeksiyon oranı çok düşük oranlarda bile olsa, bulaşık tohum kullanılmasının hastalığın fidanlıklara, fidan yastıklarına taşınmasına yol açabilecek önemli bir risk faktörü olduğunu belirtmiştir.

Tohumların yanı sıra, kozalaklar da patojenin yeni alanlara bulaşmasında ve yayılmasında oldukça önemlidir. İptal edilmiş tohum bahçelerinin (TB49, TB52, TB53, TB92) bulunduğu bölgede daha önceden yapılan çalışmalarda (Aday Kaya vd., 2019; Doğmuş-Lehtijärvi vd., 2014; Yeltekin, 2015) ve bu çalışmada, kozalaklarda da yüksek oranda $D$. sapinea bulunduğu belirlenmiştir. Dolayısıyla hem kozalak hem de tohumların kontrol edilmeden kullanımı, hastalığın fidanlıklara ya da orman alanlarına taşınmasına yol açabilecek ciddi bir risk oluşturmaktadır.

Orman hastalıklarının yeni alanlara bulaşmasında ve yayılmasında fidanlık ve ormancılık uygulamalarının etkisi oldukça önemlidir. Örneğin fidanlıklarda tohumların 
kozalaklardan çıarılmasında kullanılan ya da doğal gençleştirmede kullanılan yöntem kozalak ya da tohumda bulunan enfeksiyonun fidanlığa ya da doğal ormana bulaşma/yayılma riskini etkileyecektir. Ülkemizde, kozalaklardan tohum çıkarma işlemleri genellikle tohumların kullanılacağı orman fidanlıklarında yapılmaktadır. Kozalakların açıkta serilerek 10-15 gün kadar bekletilmesini esas alan "güneşte kurutma yöntemi" gibi yöntemlerle kozalaktan tohum çıkarma işlemleri, kozalaklar üzerinde bulunan üreme yapılarından salınan sporlar aracılığıyla hastalığın fidanlıkta üretilen fidanlara bulaşma riskini doğurabilir. Bunun aksine yüksek sıcaklıklarda $\left(55-60{ }^{\circ} \mathrm{C}\right.$ gibi) kapalı ve dar alanlarda özel 1sıtma sistemleri kullanılarak kozalaktan tohum çıkarma işlemi D. sapinea ve diğer tohum patojenlerinin tamamen yok etmese de, hem kozalaklar hem de tohumlardaki miktarını azaltabilir. Diğer taraftan, kozalaklı dal serme gibi doğal gençleştirmede kullanılan yöntemler $D$. sapinea üreme yapısı bulunduran kozalaklar aracılığıyla hastalığın doğal gençliklere bulaşma riskini doğurabilir.

Yasal önlemler, bilinen bitki hastalıklarının yayılmasının engellenmesinde etkili bir mücadele yöntemidir. Ülkemizde yakın zamanda orman bitkisi tohumluklarının üretimi ve ticaretinde usul ve esasların belirlendiği yeni yasal bir düzenleme de yapılmıştır ${ }^{1}$. Bu yasal düzenlemede orman bitkileri tohumluklarının ülke içerisindeki hareketinde istenen özel şartların belirtildiği ekte, fidanlarda Diplodia sapinea varlığının bitkisel materyal hareketliliğine mâni teşkil edebileceği belirtilirken, tohumlarda bulunabileceği göz önünde bulundurulmamıştır. Bu çalışma, şiddetli hastalık belirtisi görülen ya da hiç hastalık belirtisi görülmeyen orman alanlarından toplanan karaçam ve sarıçam tohumlarında ve kozalaklarında bu patojenin bulunabileceğini net bir şekilde ortaya koymaktadır.

Ülkemizde, tohum ekimi öncesinde tohumların kalite kontrol testleri (bindane ağırlığı, rutubet oranı ve çimlenme $\%)$ rutin olarak OATIAEM tarafindan yapılmaktadır. Bu testlere ek olarak, orman ağacı tohumlarında önemli patojenlerin varlığının belirlenmesine yönelik testlerin de yapılabilmesi için olanakların sağlanmasına yönelik adımların atılması önemlidir. Bununla birlikte hali hazırda bulunan imkânlar doğrultusunda, en azından tohum kalite özelliklerinin düşük bulunduğu durumlarda tohumlarda $D$. sapinea'nın bulunup bulunmadığının test edilmesi, hastalığın yayılışının engellenmesine yardımcı olacaktır. Fungusun varlığının test edilemediği durumlarda, düşük kaliteli tohumların kullanımından kesinlikle kaçınılması önerilebilir.

$\mathrm{Bu}$ çalışmada toplam 6 farklı tohum kaynağından gelen, iki çam türüne ait tohumlar analiz edilmiştir. Tohumlarda fungal patojenlerin tespitine yönelik testlerin yapılabileceği kurumsal laboratuvarların geliştirilmesi ve daha etkili yasal önlemlerin alınması hususundaki gerekliliğin daha net bir şekilde ortaya koyulabilmesinde, örneğin orman fidanlıklarımızdaki depolarda saklanan diğer çam türlerinin tohumlarında da $D$. sapinea'nın ya da diğer orman ağacı patojenlerinin belirlenmesine yönelik bilimsel araştırmaların yapılması faydalı olacaktır.

Tüm bunlar göz önünde bulundurulduğunda, ülkemiz koşullarında kozalak ve tohumların kontrol edilmeden kullanımının, hastalığın fidanlıklara ya da orman alanlarına taşınmasına yol açabilecek ciddi bir risk oluşturduğu anlaşılmaktadır. Bununla birlikte fidanlık ve ormancılık uygulamaları bu riskin azaltılmasında etkili bir şekilde kullanılabilir. Ülkemizde giderek daha ciddi problemlere sebep olan ve özellikle kuraklığın etkisi ile zarar şiddeti artan D. sapinea ve benzeri orman patojenlerinin yayılmasinın engellenmesinde fidanlık ve ormancılık pratiğine aktarılabilecek tekniklerin geliştirilmesine yönelik araştırmalara acilen ihtiyaç vardır.

Sonuç olarak, D. sapinea ile enfekteli tohum ve kozalakların fidanlıklara ve orman alanlarına taşınması hastalığın yayılmasında önemli bir risk faktörü olarak ele alınmalıdır. Bunun için özellikle fidanlıklara getirilecek ya da getirilen kozalak ve tohumların fungusla bulaşı olup olmadığının belirlenmesi gerekmektedir. Bununla birlikte, fidanlıklarda kozalaktan tohum çıkama işlemlerinden tohumun saklama ve ekim öncesinde görebileceği, patojen aleyhinde ancak tohum çimlenmesi üzerinde de olumsuz etkisi olmayacak fiziksel (1s1) ya da kimyasal (fungisit) uygulama olanakları üzerinde araştırmaların yapılarak uygulamaya aktarılması gerekmektedir.

\section{Açıklama}

Bu çalışmanın bir kısmı TÜBİTAK 2209/A Üniversite Öğrencileri Araştırma Projeleri Destek Programı 1919B011700637 numaralı proje tarafından desteklenmiştir. Çalışma sonuçlarının bir k1sm1 "Diseases and Insects in Forest Nurseries Working Party Meeting, 21-26 October 2018, Kuşadası, Turkey (IUFRO Working Party 7.03.04)" isimli sempozyumda sözlü olarak sunulmuş, özet metni bildiri kitabında yayınlanmamıştır.

Çalışmada kullanılan tohumların ilgili tohum bahçeleri ve meşcerelerinden toplanılmasına izin veren, arazi çalışmaları ile tohum kalite testlerinin yapılmasına kurum olanaklarını sunan Orman Ağaçları ve Tohumları Islah Araştırma Enstitüsü Müdürlüğ̈̈’ne çok teşekkür ederiz.

\section{Kaynaklar}

Adamson, K., Klavina, D., Drenkhan, R., Gaitnieks, T., Hanso, M., 2015. Diplodia sapinea is colonizing the native Scots pine (Pinus sylvestris) in the northern Baltics. European Journal of Plant Pathology, 143: 343-350.

Aday-Kaya, A.G., Yeltekin, Ş., Doğmuş-Lehtijarvi, T., Lehtijarvi, A., Woodward, S., 2019. Severity of Diplodia shoot blight (caused by Diplodia sapinea) was greatest on Pinus sylvestris and Pinus nigra in a plantation containing five pine species. Phytopathologia Mediterranea, 58: 249-259.

Aday Kaya, A., Gültekin, H.C., Karakaya, A., 2019. Marmara Bölgesindeki orman fidanlıklarında yetiştirilen odunsu bitkilerdeki fungus ve su küflerinin tespiti. Türkiye Ormancılık Dergisi, 20: 324-332.

Aday Kaya, A., Lehtijärvi, A., Kaya, Ö., Doğmuş-Lehtijärvi, T., 2014. First report of Diplodia pinea on Pseudotsuga menziesii in Turkey. Plant disease, 98: 689-689.

Akıllı, S., 2004. Türkiye'de ağaçlandırma çalışmalarında kullanılan bazı iğne yapraklı orman ağaçları tohumlarında fungal floranın tespiti. Yüksek Lisans Tezi, Ankara Üniversitesi, Fenbilimleri Enstitüsü, Orman Mühendsliği Ana Bilim Dalı Ankara.

Akıllı, S., Katırcıŏlu, Y.Z., 2006. Türkiye'de Ağaçlandırma Çalışmalarında Kullanılan Bazı Ĭğne Yapraklı Orman Ağaçları Tohumlarında Fungal Floranın Tespiti. Kastamonu Üniversitesi Orman Fakültesi Dergisi, 6: 63-73.

\footnotetext{
131 Ekim 2020, 31290: Orman Bitkisi Tohumluklari Piyasasinda Yetkilendirme, Denetleme Ve Orman Bitki Pasaportu Yönetmeliği
} 
Argun, N., Ceylan, S., Velioğlu, E., Aydın, Ü., 2014. Karaçam [Pinus nigra J. F. Arnold subsp. nigra var. pallasiana (Loudon) Rehder] tohum meşçere ve bahçelerinde üretilen tohumlarda bulunan fungusların tespiti ve fidanlardaki patojeniteleri Türkiye II. Orman Entomolojisi ve Patolojisi Sempozyumu. Orman Genel Müdürlüğü, Antalya, Türkiye, pp. 748-758.

Aslan, B., 2018. Kastamonu Taşköprü-Tekçam klonal tohum bahçesindeki kozalak zararlıları ve bazı doğal düşmanlarının araștırılması. Master, Kastamonu Üniversitesi, Fen Bilimleri Enstitüsü, Kastamonu.

Bihon, W., Slippers, B., Burgess, T., Wingfield, M.J., Wingfield, B.D., 2011. Sources of Diplodia pinea endophytic infections in Pinus patula and P. radiata seedlings in South Africa. Forest Pathology, 41: 370-375.

Blumenstein, K., Langer, G., Bußkamp, J., Langer, E., Terhonen, E., 2020. The opportunistic pathogen Sphaeropsis sapinea is found to be one of the most abundant fungi in symptomless and diseased Scots pine in Central-Europe. BMC Plant Biology. [Preprint]. https://doi.org/10.21203/rs.3.rs-48366/v1.

Brodde, L., Adamson, K., Julio Camarero, J., Castano, C., Drenkhan, R., Lehtijarvi, A., Luchi, N., Migliorini, D., Sanchez-Miranda, A., Stenlid, J., Ozdag, S., Oliva, J., 2018. Diplodia Tip Blight on Its Way to the North: Drivers of Disease Emergence in Northern Europe. Front Plant Sci, 9: 1818.

Burgess, T., Wingfield, M.J., 2002. Quarantine is important in restricting the spread of exotic seed-borne tree pathogens in the southern hemisphere. International Forestry Review, 4: 56-65.

Can, P., 2003. İzmir ve Manisa illeri Kızılçam (Pinus brutia Ten.) tohum bahçelerinde bulunan kozalak ve tohum zararlıları, zarar şekilleri ve bulunma dönemlerinin belirlenmesi üzerinde araştırmalar. Ege Üniversitesi, Fen Bilimleri Enstitüsü, İzmir.

Capretti, P., Santini, A., Solheim, H., 2013. 21 Branch and Tip Blights. Infectious Forest Diseases: 420.

Cleary, M., Oskay, F., Doğmuş, H.T., Lehtijärvi, A., Woodward, S., Vettraino, A.M., 2019. Cryptic Risks to Forest Biosecurity Associated with the Global Movement of Commercial Seed. Forests, 10: 459.

Decourcelle, T., Piou, D., Desprez-Loustau, M.L., 2015. Detection of Diplodia sapinea in Corsican pine seeds. Plant Pathology, 64: 442-449.

Deligöz, A., Gezer, A., 2005. Anadolu Karaçamı [Pinus nigra Arn. subsp. pallasiana (Lamb.) Holmboe]'Nin Bazı Tohum Meşcereleri, Klonal Tohum Bahçeleri ve Plantasyonlarında Kozalak ve Tohum Özellikleri. Türkiye Ormancılık Dergisi, 6: $1-16$.

Desprez-Loustau, M.-L., Marçais, B., Nageleisen, L.-M., Piou, D., Vannini, A., 2006. Interactive effects of drought and pathogens in forest trees. Annals of forest science, 63: 597-612.

Doğmuş-Lehtijärvi, H., Aday-Kaya, A.G., Lehtijärvi, A., Oskay, F., Kaya, Ö.D., 2014. Occurrence and genetic similarity of Diplodia pinea on shoots and cones in seed orchards of Pinus spp. in north-western Turkey. Plant Protection Science, 50: 217-220.

Doğmuş-Lehtijärvi, H., Lehtijärvi, A., Karaca, G., Aday, A., 2007. Sphaeropsis sapinea Dyko \& Sutton associated with shoot blight on Pinus brutia Ten. in Southwestern Turkey. Acta Silvatica \& Lignaria Hungarica: 95-99.

Fabre, B., Piou, D., Desprez-Loustau, M.L., Marcais, B., 2011. Can the emergence of pine Diplodia shoot blight in France be explained by changes in pathogen pressure linked to climate change? Global Change Biology, 17: 3218-3227.

Feducci, M., Pepori, A., Benassai, D., Cambi, M., Capretti, P., 2009. Cone damages by Diplodia pinea and seed boring insects on Pinus pinea 1.(italian stone pine) in central Italy. SDU Faculty of Forestry Journa, Special Issue: 41-47.

Flowers, J., Nuckles, E., Hartman, J., Vaillancourt, L., 2001. Latent Infection of Austrian and Scots Pine Tissues by Sphaeropsis sapinea. Plant Dis, 85: 1107-1112.

Fraedrich, S.W., Miller, T., Zarnoch, S.J., 1994. Factors affecting the incidence of black seed rot in slash pine. Canadian Journal of Forest Research, 24: 1717-1725.
Franic, I., Prospero, S., Hartmann, M., Allan, E., Auger-Rozenberg, M.A., Grunwald, N.J., Kenis, M., Roques, A., Schneider, S., Sniezko, R., Williams, W., Eschen, R., 2019. Are traded forest tree seeds a potential source of nonnative pests? Ecol Appl, 29: e01971.

Gezer, A., Yücedağ, C., 2006. Orman ağaçları tohumları ve tohumdan fidan yetiștirme tekniği ders kitabı. Süleyman Demirel Üniversitesi, Süleyman Demirel Üniversitesi Orman Fakültesi Isparta.

ISTA, 1996. International Rules For Seed Testing, Seed Science and Technology (Supplement), 24: 1-335

Iturritxa, E., Desprez-Loustau, M.L., García-Serna, I., Quintana, E., Mesanza, N., Aitken, J., 2011. Effect of alternative disinfection treatments against fungal canker in seeds of Pinus radiata. Seed Technology: 88-110.

Laz, B., Babur, E., Akpınar, D.M., Avgın, S.S., 2018. Kahramanmaraş-Elmalar Yeşil Kuşak Ek-3 Plantasyon Sahasında Görülen Biyotik ve Abiyotik Zararlıların Tespiti. Tarim ve Doga Dergisi, 21: 926.

Müller, M.M., Hantula, J., Wingfield, M., Drenkhan, R., 2019. Diplodia sapinea found on Scots pine in Finland. Forest pathology, 49: e12483.

Munck, I.A., Smith, D.R., Sickley, T., Stanosz, G.R., 2009. Siterelated influences on cone-borne inoculum and asymptomatic persistence of Diplodia shoot blight fungi on or in mature red pines. Forest ecology and management, 257: 812-819.

OATIAEM, O.A.v.T.I.A.E.M., 2021. Islah Tesisleri, p. https://ortohum.ogm.gov.tr/Documents/Forms/AllItems.aspx?R ootFolder $=\% 2$ fDocuments $\% 2$ fislah $\% 5$ ftesisleri\&FolderCTID $=$ 0x012000B012002E012004C64252896A64252894FBBF6425 2891D64252894DF64252890BB64252896AA64252858.

Oskay, F., Lehtijärvi, A., Dogmuş-Lehtijärvi, H., Woodward, S., 2018a. First report of Diplodia sapinea on Cedrus libani in Turkey. New Disease Reports, 38: 13-13.

Oskay, F., Lehtijärvi, A., Doğmuş Lehtijärvi, H.T., 2018b. Ülkemiz Çam Ormanlarının En Yaygın ve Tehlikeli Hastalı̆ı̆; Diplodia Sürgün Yanıklığı, in: Akinci, H.A. (Ed.), III. Türkiye Orman Entomolojisi ve Patolojisi Sempozyumu, Artvin, p. 117.

Oskay, F., Lehtijarvi, A., Doğmuş Lehtijarvi, H.T., Woodward, S., Cleary, M., 2018c. Diplodia shoot Blight in sentinel plantings in Sweden and Turkey Sentinel plantings for detecting alien, potentially damaging tree pests State of the art 2018 COST Conference, Campus Sursee, Switzerland, p. 133.

Özçankaya, İ.M., Can, P., 2006. Ege Bölgesi tohum bahçelerinde kozalak zararlılarının ve mücadele yöntemlerinin belirlenmesi. T.C. Çevre ve Orman Bakanliği Ege Ormancilik Araştirma Müdürlüğü, Ege Forestry Research Institute, İzmir.

Özkazanç, N.K., Maden, S., 2013. Some important shoot and stem fungi in pine (Pinus spp.) and firs (Abies sp.) in western Blacksea region, Turkey. Bartın Orman Fakültesi Dergisi, 15: 32-38.

Peterson, G.W., 1977. Infection, epidemiology, and control of Diplodia blight of Austrian ponderosa and Scots pines. Phytopathology, 67: 511-514.

Rees, A.A., Webber, J.F., 1988. Pathogenicity of Sphaeropsis sapinea to seed, seedlings and saplings of some central American pines. Transactions of the British Mycological Society, 91: 273-277.

Romero, G., 1997. Relationship of seed-borne pathogens to nursery and plantation diseases of eucalypts and pines in Uruguay, in: Prochazkova, Z., Sutherland, J.R., (Ed.), Proceedings of the ISTA Tree Seed Pathology Meeting. International Seed Testing Association: , Opocno, Czech Republic, pp. 82-85. 
Santini, A., Ghelardini, L., De Pace, C., Desprez-Loustau, M.L., Capretti, P., Chandelier, A., Cech, T., Chira, D., Diamandis, S., Gaitniekis, T., Hantula, J., Holdenrieder, O., Jankovsky, L., Jung, T., Jurc, D., Kirisits, T., Kunca, A., Lygis, V., Malecka, M., Marcais, B., Schmitz, S., Schumacher, J., Solheim, H., Solla, A., Szabo, I., Tsopelas, P., Vannini, A., Vettraino, A.M., Webber, J., Woodward, S., Stenlid, J., 2013. Biogeographical patterns and determinants of invasion by forest pathogens in Europe. New Phytol, 197: 238-250.

Santini, A., Pepori, A., Ghelardini, L., Capretti, P., 2008. Persistence of some pine pathogens in coarse woody debris and cones in a Pinus pinea forest. Forest Ecology and Management, 256: 502506.

Smith, D.R., Stanosz, G.R., 2006. A species-specific PCR assay for detection of Diplodia pinea and D. scrobiculata in dead red and jack pines with collar rot symptoms. Plant disease, 90: 307-313.

Smith, D.R., Stanosz, G.R., Albers, J., 2015. Detection of the Diplodia shoot blight and canker pathogens from red and jack pine seeds using cultural methods. Canadian Journal of Plant Pathology, 37: 61-66.

Smith, H., Wingfied, M.J., Coutinho, T.A., 2002. The role of latent Sphaeropsis sapinea infections in post-hail associated die-back of Pinus patula. Forest Ecology and Management, 164: 177184.

Smith, H., Wingfield, M.J., Coutinho, T.A., Crous, P.W., 1996. Sphaeropsis sapinea and Botryosphaeria dothidea endophytic in Pinus spp. and Eucalyptus spp. in South Africa. South African Journal of Botany, 62: 86-88.

Smith, H., Wingfield, M.J., de Wet, J., Coutinho, T.A., 2000. Genotypic Diversity of Sphaeropsis sapinea from South Africa and Northern Sumatra. Plant Dis, 84: 139-142.

Soylu, S., Kurt, Ş., Soylu, E., 2001. Determination of important fungal disease agents on pine trees in the Kahramanmaraş regional forests. Journal of Turkish Phytopathology, 30: 79.

Stanosz, G., Blodgett, J., Smith, D., Kruger, E., 2001a. Water stress and Sphaeropsis sapinea as a latent pathogen of red pine seedlings. New Phytologist, 149: 531-538.

Stanosz, G.R., Blodgett, J.T., Smith, D.R., Kruger, E.L., $2001 \mathrm{~b}$. Water stress and Sphaeropsis sapinea as a latent pathogen of red pine seedlings. New Phytologist, 149: 531-538.

Stanosz, G.R., Smith, D.R., Guthmiller, M.A., Stanosz, J.C., 1997. Persistence of Sphaeropsis sapinea on or in Asymptomatic Shoots of Red and Jack Pines. Mycologia, 89: 525-530.
Stanosz, G.R., Smith, D.R., Leisso, R., 2007. Diplodia shoot blight and asymptomatic persistence of Diplodia pinea on or in stems of jack pine nursery seedlings. Forest Pathology, 37: 145-154.

Sümer, S., 2000. Shoot Blight Disease Caused by Sphaeropsis sapinea in Pine Stands at the South-Eastern Region, Turkey. (OGM inceleme raporu)

Şanlı, B.N., Balkız, B., Çelik, O., Semerci, A., Şahin, Ö., 2010. Some Tree Mortality Cases Based on Drought Insect and Diseases in Turkey, EFIMED Annual Progress Meeting and Scientific Seminar "Knowledge-based management of Mediterranean forests under climate driven risks: the ways ahead", Antalya, Turkey.

Ünal, F., Koca, E., Aşkın, A., Kurbetli, İ., Sarpkaya, K., 2018. Identification and virules of Sphaeropsis tip blight (Sphaeropsis sapinea) on Pinus spp. in Istanbul and Bursa parks. Acta Biologica Turcica, 31: 18-21.

Ünligil, H., Ertaş, A., 1993. İstanbul yakınlarındaki çam ağaçlarında Sphaeropsis sapinea (Fr.) Dyko \& Sutton mantar hastalığı. İstanbul Üniversitesi Orman Fakültesi Dergisi, 43: 131-138.

Velioğlu, E., 2001. Detection of Fungal Flora in Certain Forest Tree Seeds. Ministry of Forestry, Ankara.

Vujanovic, V., St-Arnaud, M., Neumann, P.J., 2000. Susceptibility of cones and seeds to fungal infection in a pine (Pinus spp.) collection. Forest Pathology, 30: 305-320.

White, T., Bruns, T., Lee, S., Taylor, J., 1990. Amplification and direct sequencing of fungal ribosomal RNA genes for phylogenetics. In: Innis, M.A., Gelfand, D.H., Sninsky, JJ, White TJ, eds. PCR Protocols: A Guide to Methods and Applications. New York, USA: Academic Press Inc., ss. 315322.

Yeltekin, Ş., 2015. Kerpe araştırma ormanı konifer türlerinde Diplodia spp.'den kaynaklanan kozalak ve sürgün enfeksiyonlarının belirlenmesi. Süleyman Demirel Üniversitesi, Fen Bilimleri Enstitüsü, Orman Mühendisliği Ana Bilim Dalı, Isparta.

Zakaullah, A.F., 2000. Mycoflora associated with blue pine seed. Pakistan Journal of Forestry, 50: 25-31.

Zlatković, M., Keča, N., Wingfield, M.J., Jami, F., Slippers, B., Kim, M.S., 2017. New and unexpected host associations for Diplodia sapinea in the Western Balkans. Forest Pathology, 47: e12328. 